\title{
John LACHS, The Cost of Comfort
}

Bloomington, Indiana University Press, 2019, 101 pages

\section{Charles Padrón}

\section{(2) OpenEdition \\ Journals}

Electronic version

URL: http://journals.openedition.org/ejpap/2033

ISSN: 2036-4091

\section{Publisher}

Associazione Pragma

\section{Electronic reference}

Charles Padrón, « John LACHS, The Cost of Comfort », European Journal of Pragmatism and American Philosophy [Online], XII-1 | 2020, Online since 16 June 2020, connection on 23 September 2020. URL http://journals.openedition.org/ejpap/2033

This text was automatically generated on 23 September 2020 .

\section{(1) () ()}

Author retains copyright and grants the European Journal of Pragmatism and American Philosophy right of first publication with the work simultaneously licensed under a Creative Commons AttributionNonCommercial-NoDerivatives 4.0 International License. 


\title{
John LACHS, The Cost of Comfort
}

\author{
Bloomington, Indiana University Press, 2019, 101 pages
}

\section{Charles Padrón}

\section{REFERENCES}

John LACHS, The Cost of Comfort. Bloomington: Indiana University Press, 2019, 101 pages

1 John Lachs tells us in the short "Preface" to his latest book that in an earlier work, " Intermediate Man, a book I wrote some years ago," (1981) he "presented similar ideas. But this book is significantly different from the earlier. It covers more topics and makes, I hope, a more compelling case for my analysis" (p. vii). He goes on to state that in The Cost of Comfort one can find his analysis of contemporary life a "testable form," given over to an invitation to experiment (similar to another contemporary philosopher, Anthony Appiah in his Experiments in Ethics, 2008), to put into play, his ideas as to how mediation impacts our lives, how it removes certain capacities from our well-being and authenticity as living beings, while at the same time for the most part positively contributing to a certain lessening of stress, anxieties, and downright drudge-work in our need to continue our existences and furthering our physical lives. This is the dynamic of this short, but densely argued philosophical work: the give and take of what we gain from living in a complex, multi-layered world of human interrelationships that make possible a certain standard of life, juxtaposed against the inevitable range of possibilities and activities that we must relinquish, give up as it were, in order to maintain that cushion of "comfort." In short, the price we pay for the lives we have and lead. This is especially self-evident in 2020, during which the Covid-19 pandemic has compelled the citizenry of planet Earth to take stock of the interrelatedness all human beings exist amidst.

2 Mediation is the entry point into an understanding of Lachs' arguments. Given its priority, what, precisely, does it signify for him? In his earlier work, Intermediate Man, he utilized the example from Defoe's fictional creation, Robinson Crusoe, of the protagonists Crusoe and Friday as explanatory models, defining mediation in its rawest 
manifestation, that which can exist between merely two individuals. Writing about the ubiquity of the mediation's applicability, Lachs claims that "we find it in the rudimentary one of Crusoe and Friday no less than in a Marxist utopia. This fact is that of mediation or action on behalf of the other. Without our Fridays each of us would have to perform by himself all of the actions that support his life and express himself" (Lachs, Intermediate Man, Hackett 1981: 11). Conversely, and somewhat in a more expansive reach, he writes in The Cost of Comfort:

None of us can accomplish anything of social significance without continued participation of all the rest. In large-scale actions, then, others are interposed between me and the outcome of my acts. I find myself in a similar position, occupying a place between others and the results of their endeavors. I shall call this interposition of others between oneself and the complete act (which includes the consequences) mediation. (17)

3 The definitions parallel each other, and co-extend each other. To frame it differently, in coarser terms: Is it plausible, even reasonable, to think about human lives, or one human life, apart from other human lives? Aside from being an excruciatingly pathetic, arduous state of affairs, human life without any mediation, would be brutal and cruel. How can a human life be appreciated except as shared with and dependent on others? It simply cannot - unless of course, human life is reduced to Crusoe-like conditions, or like Thoreau close to his pond. Yet let us recall, Crusoe did not spend his entire life on the island (twenty-eight years), and Thoreau only roughly twenty-six months on Walden both not examples of a human life cycle. The question itself compels us to delve deeper into a clearly inconceivable existence that most of us would never care to venture upon. So, yes, there is an inextricable link between Intermediate Man and The cost of Comfort, and that link centers in the notion of mediation.

4 Now, this acknowledged, what arguments does Lachs further in this new book? He tells us that there are six inevitable outcomes of mediation, or as he designates them, "consequences." But before doing so, Lachs brings into the conversation the notion of immediacy. This notion he extrapolates from two other philosophers, Hegel and Peirce, both culpable in reducing (even effacing) the necessary centrality of the immediacy in a human life that maintains "value and goodness," and which provides us with "pleasure, satisfaction, enjoyment and delight" (25). Hegel eviscerated the momentousness of immediacy with his totalizing effort in the Phenomenology at establishing the "ubiquity" of mediation, and Peirce's overemphasized the "thirds," (thoughts, laws, rules, signs) rather than the "firsts," which are "immediate feelings and private apprehensions," thereby disregarding the importance of immediacy, a notion that I am sure Lachs would claim as indispensable to a meaningful life.

5 These two notions, mediation and immediacy, in their tensional dynamic, help Lachs to lay out his arguments as to why there needs to be more of the latter and less of the former as we careen on into the challenges of the twenty-first century. This is especially applicable in his discussions of two sets of facets to the reality of mediation: one group is a list of tolls it takes on human lives (passivity, impotence, ignorance, manipulation, psychic distance, and irresponsibility); the second group is a number of civilizational forces that circumscribe and define our everyday existences (tools, language, ideology, institutions, and government). The first represents what over-mediation engenders; the second group identifies the primary instruments, the means used, to create and perpetrate that engendering. These discussions are critical and lively, and make up forty pages, nearly half of the book. 
Defining each of these six notions as they relate to mediation would be helpful here, all of them interwoven, and I will employ Lachs' own words to do so. Passivity "is easy to explain. So long as others set the parameters of our lives and determine our daily activities, it is difficult not to feel put upon" (31-2). Stated differently - as long as I am relatively sure that water will continue to course through my faucets and sinks, that electricity will continue to alight the lighting in my house and turn on my computer, then why would I need to worry about it? I become passive to its being a fact of my life, and assume, both correctly and erroneously that it will always be the case - at least for the near future. But what occurs within myself when, assuming it is always going to be there, I place my entire livelihood in my activities with my computer, and either the weather or a natural calamity or some massive crash of the system occurs, shutting it down, a totally unforeseen occurrence - I feel powerless, because I am left no options to secure do what I need to do - i.e., I am impotent. I am impotent due to the fact that I did not plan ahead, that I was passive. Lachs writes: "The sense of passivity can readily turn into a feeling of bitter impotence" (33). And the more layered and complex our situation is, and further we are removed from the source of the mediation that provides us with some product or service, the more intense can be the sense of impotence. Ignorance is interwoven with the previous two. For the more passive one becomes, and potentially the more the sense of impotence augments, both can be aggravated by the ignorance one lives amidst. Lachs writes:

Working in large institutions, people have little idea of the complex wholes to which they contribute [...] social acts performed have no idea how they came about [...] Today, by contrast, we have direct knowledge of only a few sorts of actions; for everything else that may be needed, we have to call in specialists [...] The vaunted ideal of the Renaissance person is not to be conceived in terms of extent of knowledge but scope of skill and experience. Mediation provides us with much unimportant information at the price of surrendering full-bodied engagement with life. (38-9)

Ignorance, willful or not, opens one up to the vulnerability of manipulation, for "mediated chains invite manipulation, and manipulation undermines the moral structure of human interactions. The ultimate results are inability to distinguish sincere from artificial sentiments and reluctance to trust anything" (41). Imagine the brilliant engineer at work on a top-secret project to create a super "smart" missile that he or she believes will be used to defend the country that said engineer is a citizen of. Now, at some stage of the game, some clog in the bureaucracy of the defense maze of national security decides to divert the missile technology to a third party, say an authoritarian regime, a terrorist organization, or even a declared enemy of one's own nation, for money. Not only has one's knowledge been manipulated, but one's very authenticity, one's innermost credo, what one believed one was working for (a more secure nation for one's loved ones, one's children, one's fellow citizens) has been violated and abused. It is hard to imagine how trust could ever be restored for someone who has experienced such a deception. Psychic distance (a notion that Lachs first broached in Intermediate Man as "a direct result of the lack of direct experience. It shows itself in our unwillingness or even inability to appropriate actions that are clearly ours" (Lachs, Intermediate Man: 13)) results from ignorance:

When actions are performed by others on my behalf, typically I have no direct experience of the act. In some important sense, the action performed for me is mine [...] Specialists do everything or almost everything for me, and I end up in isolation from my roots and leaves. (43) 
As Lachs has written in another context in the book, and I paraphrase, we know not what we do. And finally, the last notion on this list of consequences is the inevitable outcome of irresponsibility, the twisted and irrevocable existential knot of refusing to claim or assume self-responsibility for something we are not sure about, or are totally ignorant of, since we are ignorant of the other factors that contribute to our actions, or the farranging extent of the influence of them: "Irresponsibility grows out of the inability and unwillingness of individuals to appropriate the actions to which they contribute [...] They think they are hired hands who can shrug their shoulders when things don't go right and disclaim responsibility by saying they were just following orders or someone else's design" (47).

9 The sweep of the range of "mediators" covers a vast swath of our everyday lives, covering most everything that links humans to other humans, bridging any sort of primeval condition separating humans from their counterparts. The first of these are tools, which were invented, perfected, and used, all to the benefit of humans, but now "the growth of technology changed the balance of power: instead of being their helpmate, in certain respects technology turned humans into appendages of machines" (51); technology has not turned on humans, but the one-way relationship of being a helpful aid has changed. Next is language, the currency of talk or conversation, which "takes the place of direct experience [...] We need to acknowledge its value in making large-scale human communication possible" (52-4). Lachs' cherished immediacy can be lost completely in the fog of layer upon layer of words, or as he writes "a sea of talk" (52). In many instances and situations in life, words are not needed. Formulating them, and then responding to them on the part of others, merely blurs understanding and communication. Ideology is the fourth mediating generating element in our world today. Lachs writes:

As a way of thinking, ideology becomes a mediating force structuring the relations of human beings. Its followers find it difficult to view people as living and suffering individuals. Instead, they think of them as instances of stereotypes - that is as women, Jews, blacks, infidels, or capitalists. This destroys the human kinship between oneself and others, displaying whoever does not agree with the ruling way of thought as blind or alien. (56)

Or the non-ruling. One does not have to be a part of a way of thinking (or a member of a specific political party or a member or functionary in an institution) to possess an ideology. And the fifth and sixth of Lachs' mediating culprits (institutions and government) share with ideology a we vs. them mentality, and even within an institution or a government these forces may be at work, with internal rules and policies to boot, almost rendering impossible any authentic immediacy in the interactions between human beings. To say nothing of those outside of these institutions and governments. To use an example from the American context, like those who work for the US Dept. of Justice, all others who are not integral to their mission and ranks are non-us, and justice (just-us), is what reigns. All six of these mediating forces that Lachs has identified share one thing: that though they have helped to create the current level of civilized life in the early twenty-first century, they conversely have contributed to making that civilized life more difficult and stressful. The question for Lachs, and the principal question that dominates the raison d'être of this book is: how do we adjust the balance to the point where the stress and difficulties are lessened and rendered more manageable, and are not so overwhelming and stifling? What does Lachs argue for and see for the future? 
11 First, we must comprehend that mediation is here to stay - that civilized, social life demands many degrees of mediation. That indeed, our level of well-being and good fortune is in direct proportion to the benefits brought about by what has been achieved by mediating efforts. However, sadly, Lachs' forecast for the future is replete with some vague what-ifs, some hypothetical wishful thinking, but is sparse in concrete proposals, apart from some that contradict what Lachs as a philosopher has espoused in the past, and this seems perplexing to those who know Lachs' œuvre. Lachs published another book, Meddling, in 1914 in which he basically and quite unreservedly lambastes efforts on the part of anyone or any collective (government, institutions, and individuals) to interfere and prescribe what they think is best for others, both on macro and micro scales. In fact, he wrote in the "Introduction" to a book published two years before Meddling (Stoic Pragmatism, 2012) the following: "The stoic side of my view explains also my conviction that many things riling people greatly really do not matter at all. This is the foundation of my desire to leave people alone to conduct their lives as they fit, that is, of my respect for autonomy and also of the tolerant attitude I take to the harmless varieties of human nature" (Lachs, Stoic Pragmatism, Indianapolis, 2012: 2). It just might be the case that for many other thinkers and concerned minds Lachs' mediation and immediacy are two notions that rile Lachs to the point of forgetting or letting pass over other, seemingly far more pressing, threatening, and consequential problems and questions that we are encountering in our contemporary world. They seem to be not that absorbing to Lachs (the environment, world hunger, poverty, corruption, and the prevalence of an atavistic strain of arrogant populism and authoritarianism). To be sure, the "cost of comfort" is a high price we pay to perpetrate our lives lived out in our first world of twenty-first century development and organized social life. But what is the alternative, at this stage of the game? Maybe a start would be a humble recognition that we do not need any more rules or prescribed ways of acting and valuing ("...we must devise rules for holding every person in a mediated chain responsible for the mayhem caused" 97). Is this even tenable? And a second start might be something to the extent that we could recognize an idea put forth by the contemporary German thinker, Peter Sloterdijk, of co-immunism, or an awareness that each individual is compromised to a recognition of mutual concern and protectiveness (of others), and that basic, common survival for us as a species requires that we become aware that countries, nationalities, classes, do not give anyone safe conduct to privilege or survival, or privileged survival. And given the onset of this pandemic, baffling and lethal, Covid-19, this idea is even more spot-on and portentous. It just might very well be the case that a complete overhaul in our comprehension of what immediacy means for us lies ahead in the 2020s. Other notions such as the other, distance, and decency, might also undergo radical transmogrifications.

12 Lachs' book is a fitting final touch to his lifelong work and teaching, and as this it is an edifying work of profound, reflective philosophical thought. Lachs has always evidenced such an attraction and interpretive intention, and this work is a further product of such a mind, a lucid one, whose interests always, in the final say, side with the best examples of our generous, yet commonsensical, aspects of who we are as human beings, always defying the non-personal, the abstract, the exhausting onslaughts of all kinds of forces we are subject to, and continuously confront on a daily basis - which have the power, if unchecked, to destroy us. It is only to be hoped that we have the wisdom to cull from the 101 pages of this text that which can indeed serve us well, as the twenty-first century surges on, racing on into a context of possibilities that 
can only be called, modestly, challenging. Lachs has given us much to ponder over, and to cherish.

\section{AUTHORS}

\section{CHARLES PADRÓN}

Gran Canaria, Spain. Berlin Practical Philosophy International Forum, e.V. padron.charles[at]yahoo.com 